Article

\title{
Impact of SRY-Box Transcription Factor 11 Gene Polymorphisms on Oral Cancer Risk and Clinicopathologic Characteristics
}

\author{
Chia-Ming Yeh ${ }^{1,2,3}$, Chiao-Wen Lin ${ }^{4,5}$, Hsueh-Ju Lu ${ }^{6,7}$, Chun-Yi Chuang ${ }^{7,8}$, Chia-Hsuan Chou ${ }^{1}$, \\ Shun-Fa Yang $1,9, * \mathbb{D}$ and Mu-Kuan Chen ${ }^{1,2,3, *}$ \\ 1 Institute of Medicine, Chung Shan Medical University, Taichung 402, Taiwan; \\ yehcm0525@outlook.com (C.-M.Y.); wishwing1109@hotmail.com (C.-H.C.) \\ 2 Cancer Research Center, Changhua Christian Hospital, Changhua 500, Taiwan \\ 3 Department of Otorhinolaryngology-Head and Neck Surgery, Changhua Christian Hospital, \\ Changhua 500, Taiwan \\ 4 Institute of Oral Sciences, Chung Shan Medical University, Taichung 402, Taiwan; cwlin@csmu.edu.tw \\ 5 Department of Dentistry, Chung Shan Medical University Hospital, Taichung 402, Taiwan \\ 6 Division of Medical Oncology, Department of Internal Medicine, Chung Shan Medical University Hospital, \\ Taichung 402, Taiwan; hsuehju0311@gmail.com \\ 7 School of Medicine, Chung Shan Medical University, Taichung 402, Taiwan; cyi4602@gmail.com \\ 8 Department of Otolaryngology, Chung Shan Medical University Hospital, Taichung 402, Taiwan \\ 9 Department of Medical Research, Chung Shan Medical University Hospital, Taichung 402, Taiwan \\ * Correspondence: ysf@csmu.edu.tw (S.-F.Y.); 53780@cch.org.tw (M.-K.C.)
}

Received: 29 May 2020; Accepted: 22 June 2020; Published: 23 June 2020

check for updates

\begin{abstract}
Oral cancer is among the most common cancers worldwide and has become a major global health problem because of its relatively high morbidity and mortality rates. The sex-determining region on the Y-chromosome-related high-mobility-group box (SOX) transcription factor 11 (SOX11) plays a key role in human development and differentiation and is frequently increased in various human cancers. However, the clinical significance of SOX11 polymorphisms in oral cancer and their association with oral cancer risk are unclear. In this study, we included 1196 patients with oral cancer and 1200 controls. Real-time polymerase chain reaction was applied to analyze three SOX11 single-nucleotide polymorphisms (rs77996007, rs66465560, and rs68114586). Our results shown that SOX11 polymorphisms carriers with betel quid chewing were found to have an 8.38- to 9.23-fold risk to have oral cancer compared to SOX11 wild-type carriers without betel quid chewing. Furthermore, oral cancer patients who carried SOX11 rs77996007 “TC + CC" variants were significantly associated with large tumor size (AOR, 1.324; 95\% CI, 1.047-1.674; $p=0.019$ ). Moreover, a database analysis using the Cancer Genome Atlas suggested that SOX11 mRNA expression was high during the tumor development process. In conclusion, our results suggest that SOX11 rs77996007 is involved in oral cancer progression and clinical characteristics.
\end{abstract}

Keywords: SOX11; oral squamous cell carcinoma; single nucleotide polymorphisms; metastasis

\section{Introduction}

Oral and pharyngeal cancer has an annual incidence of approximately 5 million and causes approximately 25,000 deaths each year in the United States. Cancers of the oral cavity and the pharynx are among the most common cancers in the world. Nearly 53,000 new cases of oral and pharyngeal cancer and 10,860 deaths were recorded in 2019 worldwide, with a wide geographical variation in incidence being reported [1]. More than $90 \%$ of oral cancer cases involve oral squamous cell carcinoma 
(OSCC), which has become a global health problem because of its relatively high morbidity and mortality rates [2]. Surgery and chemoradiotherapy are the main treatments for oral cancer. Despite considerable progress in the treatment of oral cancer, the 5-year survival rate for advanced (stage III and IV) oral cancer is approximately 20\% [3]. Tobacco and alcohol are the main risk factors for oral cancer. The risk of oral cancer increases when both factors are present. Exposure to one or both factors can explain approximately $70 \%$ of cancers in this region $[4,5]$.

The sex-determining region on the Y-chromosome-related high-mobility-group box (SOX) transcription factor family contains more than 20 members in vertebrates; these members are divided into eight groups, spanning from SOXA to SOXH [6-8]. These genes originated in a series of evolutionary processes, including replication and divergence [8,9], and were identified more than 20 years ago. Since then, numerous studies have demonstrated their fundamental and dynamic functions in embryonic development and diseases [7,10]. SOX transcription factors play a major role in regulating stem cell maintenance and terminal differentiation of different cell types [11]. SOX11 belongs to the SOXC group, which also includes SOX4 and SOX12 [12]. SOX11 plays a key role in human development and differentiation. Sox11-deficient mice die of cardiac artery outflow tract malformations, suggesting that Sox11 has a vital function in tissue remodeling [13]. Recent studies have shown that SOX11 messenger RNA (mRNA) is frequently increased in various human cancers, including breast cancer [14], mantle cell lymphoma [15], gastrointestinal cancer [16], epithelial ovarian cancer [17], and nervous system neoplasms. SOX11 upregulation promotes epithelial-to-mesenchymal transition in breast cancer cells [18]. A single-nucleotide polymorphism (SNP) is a common genetic variation that can affect protein expression and structure and lead to disease susceptibility [19]. The genetic polymorphisms of SOX transcription factors have been associated with the risk of numerous cancer types, including gallbladder cancer [20], breast cancer [21], and endometrial cancer [22]. Moreover, recent studies have reported that both the SOX11 gene and protein expression were significantly overexpressed in recurrent oral cancer tissues and may promote oral cancer invasion and progression [23,24]. However, no studies have explored the correlation between SOX11 SNPs and oral cancer.

Accordingly, we conducted this case-control study to investigate the relationship between three SOX11 gene polymorphisms (rs77996007, rs66465560, and rs68114586) and clinical pathological characteristics of oral cancer patients in order to identify patients at an increased risk of oral cancer and provide a theoretical basis for further clinical prevention of oral cancer.

\section{Results}

\subsection{Characteristics of Study Participants}

This study included 2396 participants, and Table 1 presents descriptive statistics for the demographic characteristics of the participants. The participants comprised 1196 patients with OSCC (case group) and 1200 controls (control group). The results revealed a statistically significant difference in betel chewing $(p<0.001)$, cigarette smoking $(p<0.001)$, and alcohol drinking $(p<0.001)$ between the case and control groups. However, differences in age distribution between the two groups were not statistically significant $(p=0.966)$. 
Table 1. The distributions of demographical characteristics in 1200 controls and 1196 male patients with oral cancer.

\begin{tabular}{llll}
\hline \multicolumn{1}{c}{ Variable } & Controls $(\boldsymbol{n = 1 2 0 0 )}$ & Patients $(\boldsymbol{n}=\mathbf{1 1 9 6 )}$ & $p$-Value \\
\hline Age (yrs) & $610(50.8 \%)$ & $609(50.9 \%)$ & $p=0.966$ \\
$\leqq 55$ & $590(49.2 \%)$ & $587(49.1 \%)$ & \\
$>55$ & & & \\
Betel quid chewing & $1001(83.4 \%)$ & $321(26.8 \%)$ & $p<0.001^{*}$ \\
No & $199(16.6 \%)$ & $875(73.2 \%)$ & \\
Yes & $564(47.0 \%)$ & $192(16.0 \%)$ & \\
Cigarette smoking & $636(53.0 \%)$ & $1004(84.0 \%)$ & \\
No & & & \\
Yes & $963(80.2 \%)$ & $648(54.2 \%)$ & \\
Alcohol drinking & $237(19.8 \%)$ & $548(45.8 \%)$ & \\
No & & & \\
Yes & & $565(47.2 \%)$ & \\
Stage & & $631(52.8 \%)$ & \\
I + II & & $599(50.1 \%)$ & \\
III + IV & & $597(49.9 \%)$ & \\
Tumor T status & & & \\
T1 + T2 & & $796(66.6 \%)$ & \\
T3 + T4 & & $400(33.4 \%)$ & \\
Lymph node status & & & \\
N0 & & $1186(99.2 \%)$ & \\
N1 + N2 + N3 & & $10(0.8 \%)$ & \\
Metastasis & & $170(14.2 \%)$ & \\
M0 & & $1026(85.8 \%)$ & \\
M1 & & & \\
Cell differentiation & & & \\
Well differentiated & & & \\
Moderately or poorly & & & \\
differentiated & & & \\
\hline
\end{tabular}

Fisher's exact test was used between healthy controls and patients with oral cancer. * $p$-value $<0.05$ was considered statistically significant.

\subsection{Association of SOX11 Polymorphisms with Oral Cancer Risk}

To investigate the association between the allele frequency of SOX11 SNPs and the risk of oral cancer, the allele frequencies of SOX11 rs77996007, rs66465560, and rs68114586 in the case and control groups were tested (Table 2).

Table 2. The adjusted odds ratio (AOR) and 95\% confidence interval (CI) of oral cancer associated with SOX11 genotypic frequencies.

\begin{tabular}{|c|c|c|c|c|}
\hline Variable & $\begin{array}{l}\text { Controls } \\
(n=1200)(\%)\end{array}$ & $\begin{array}{l}\text { Patients } \\
(n=1196)(\%)\end{array}$ & OR $(95 \%$ CI) & $\operatorname{AOR}(95 \% \mathrm{CI})^{b}$ \\
\hline \multicolumn{5}{|l|}{ rs77996007 } \\
\hline $\mathrm{TT}$ & $514(42.8 \%)$ & $470(39.3 \%)$ & 1.000 (reference) & 1.000 (reference) \\
\hline $\mathrm{TC}$ & $526(43.8 \%)$ & $586(49.0 \%)$ & $1.218(1.026-1.446)^{a}$ & $1.076(0.871-1.328)$ \\
\hline $\mathrm{CC}$ & $160(13.4 \%)$ & $140(11.7 \%)$ & 0.957 (0.739-1.240) & $0.923(0.670-1.271)$ \\
\hline $\begin{array}{l}\mathrm{TC}+\mathrm{CC} \\
\text { rs66465560 }\end{array}$ & $686(57.2 \%)$ & $726(60.7 \%)$ & rs66465560 & $1.042(0.853-1.272)$ \\
\hline TT & $911(75.9 \%)$ & $921(77.0 \%)$ & 1.000 (reference) & 1.000 (reference) \\
\hline $\mathrm{TC}$ & $271(22.6 \%)$ & $265(22.2 \%)$ & $0.967(0.798-1.173)$ & $0.965(0.762-1.223)$ \\
\hline $\mathrm{CC}$ & $18(1.5 \%)$ & $10(0.8 \%)$ & $0.550(0.252-1.197)$ & $0.424(0.163-1.099)$ \\
\hline $\begin{array}{l}\mathrm{TC}+\mathrm{CC} \\
\text { rs68114586 }\end{array}$ & $289(24.1 \%)$ & $275(23.0 \%)$ & $0.941(0.779-1.137)$ & $0.929(0.736-1.171)$ \\
\hline Ins/Ins & $912(76.0 \%)$ & $921(77.0 \%)$ & 1.000 (reference) & 1.000 (reference) \\
\hline Ins/Del & $269(22.4 \%)$ & $264(22.1 \%)$ & $0.972(0.801-1.179)$ & $0.978(0.772-1.240)$ \\
\hline Del/Del & $19(1.6 \%)$ & $11(0.9 \%)$ & $0.573(0.271-1.211)$ & $0.435(0.174-1.090)$ \\
\hline Ins/Del or Del/Del & $288(24.0 \%)$ & $275(23.0 \%)$ & $0.946(0.783-1.142)$ & $0.939(0.745-1.184)$ \\
\hline
\end{tabular}

The odds ratio (OR) with their $95 \%$ confidence intervals were estimated by logistic regression models. ${ }^{\text {a }} p=0.024$.

$\mathrm{b}$ The adjusted odds ratio (AOR) with their $95 \%$ confidence intervals were estimated by multiple logistic regression models after controlling for age, betel quid chewing, cigarette smoking, and alcohol drinking.

The allele frequencies of SOX11 rs77996007, rs66465560, and rs68114586 were predominantly distributed in the controls and patients with oral cancer heterozygous for TC, homozygous for TT, and homozygous for Ins/Ins. Patients who carried SOX11 rs77996007 TC were at a higher risk of oral 
cancer compared with the controls $(\mathrm{OR}=1.218 ; 95 \% \mathrm{CI}=1.026-1.446)$. However, after adjustment for age, betel quid chewing, cigarette smoking, and alcohol drinking, no significant difference in distributions of SOX11 SNPs rs77996007, rs66465560, or rs68114586 was observed between the case and control groups (Appendix A, Table A1).

\subsection{Association of SOX11 SNPs with Oral Cancer Risk Considering Betel Quid Chewing}

Table 3 presents the associations between environmental risk factors and genetic polymorphisms of SOX11. We conducted further analysis on 1640 smokers who had SOX11 polymorphic rs77996007, rs66465560, or rs68114586. Smokers who had a betel-quid-chewing habit and at least one $\mathrm{C}$ allele of rs77996007, one C allele of rs66465560, or one Del allele of rs68114586 had a 9.225- (95\% CI: 6.610-12.874), 8.376- (95\% CI: 5.735-12.234), or 8.653-fold (95\% CI: 5.913-12.664) higher risk of oral cancer than did individuals with the WT gene who did not have a betel-quid-chewing habit. In light of the above results, we suggested that the SOX11 gene polymorphisms have an impact on oral cancer susceptibility in betel nut consumers.

Table 3. Associations of the combined effect of SOX11 gene polymorphisms and betel nut chewing with the susceptibility to oral cancer among 1640 smokers.

\begin{tabular}{|c|c|c|c|c|}
\hline Variable & $\begin{array}{l}\text { Controls }(n=636) \\
(\%)\end{array}$ & $\begin{array}{l}\text { Patients }(n=1004) \\
(\%)\end{array}$ & OR $(95 \% \mathrm{CI})$ & AOR $(95 \% \mathrm{CI})$ \\
\hline \multicolumn{5}{|l|}{ rs779996007 } \\
\hline TC or CC genotype or betel nut chewing & $330(51.9 \%)$ & $406(40.4 \%)$ & $2.804(2.094-3.755)$ & $2.623(1.949-3.530)$ \\
\hline TC or CC genotype with betel nut chewing & $110(17.3 \%)$ & $512(51.0 \%)$ & $\begin{array}{l}10.608 \\
(7.652-14.705)\end{array}$ & $9.225(6.610-12.874)$ \\
\hline TC or CC genotype or betel nut chewing & $252(39.6 \%)$ & $678(67.5 \%)$ & $6.551(5.126-8.372)$ & $5.872(4.575-7.535)$ \\
\hline $\begin{array}{l}\text { TC or CC genotype with betel nut chewing } \\
\text { rs } 68114586\end{array}$ & $48(7.6 \%)$ & $188(18.7 \%)$ & $9.536(6.562-13.859)$ & $8.376(5.735-12.234)$ \\
\hline Ins/Ins genotype \& non-betel nut chewing & $338(53.1 \%)$ & $138(13.8 \%)$ & 1.000 (reference) & 1.000 (reference) \\
\hline $\begin{array}{l}\text { Ins/Del or Del/Del genotype or betel nut } \\
\text { chewing }\end{array}$ & $251(39.5 \%)$ & $677(67.4 \%)$ & $6.606(5.169-8.443)$ & $5.934(4.625-7.613)$ \\
\hline
\end{tabular}

\subsection{Association between SOX11 Polymorphic Genotypes and Clinical Features of Oral Cancer}

We investigated the role of SOX11 genetic polymorphisms in the clinical status of oral cancer. Table 4 shows the distribution frequency of clinical features, such as clinical stage, tumor size, lymph node or distant metastasis, and cell differentiation grade, and SOX11 genotype frequencies in patients with oral cancer. Compared with individuals who were homozygous for the WT allele of rs77996007, patients with at least one $C$ allele of rs77996007 were significantly associated with larger tumor size after controlling for age, betel quid chewing, cigarette smoking, and alcohol drinking (AOR, 1.324; 95\% CI, 1.047-1.674; $p=0.019$ ). However, we did not observe a significant association between SOX11 genotype frequencies of rs77996007 and clinical stage, lymph node or distant metastasis, or cell differentiation grade. 
Table 4. The adjusted odds ratio (AOR) and 95\% confidence intervals (CI) of clinical statuses associated with genotypic frequencies of SOX11 rs77996007 in male oral cancer patients $(n=1196)$.

\begin{tabular}{|c|c|c|c|c|}
\hline \multicolumn{3}{|c|}{ Variable } & AOR $(95 \% \mathrm{CI})$ & $p$-Value \\
\hline & \multicolumn{4}{|l|}{ Clinical Stage } \\
\hline rs77996007 & $\begin{array}{l}\text { Stage I + II } \\
(n=565)(\%)\end{array}$ & $\begin{array}{l}\text { Stage III + IV } \\
(n=631)(\%)\end{array}$ & & \\
\hline TT & $238(42.1 \%)$ & $232(36.8 \%)$ & 1.00 & \\
\hline \multirow[t]{2}{*}{$\mathrm{TC}+\mathrm{CC}$} & $327(57.9 \%)$ & $399(63.2 \%)$ & $1.252(0.991-1.582)$ & $p=0.060$ \\
\hline & \multicolumn{4}{|l|}{ Tumor size } \\
\hline rs77996007 & $\begin{array}{l}\leqq \mathrm{T} 2 \\
(n=599)(\%)\end{array}$ & $\begin{array}{l}>\mathrm{T} 2 \\
(n=597)(\%)\end{array}$ & & \\
\hline TT & $255(42.6 \%)$ & $215(36.0 \%)$ & 1.00 & \\
\hline \multirow[t]{2}{*}{$\mathrm{TC}+\mathrm{CC}$} & $344(57.4 \%)$ & $382(64.0 \%)$ & $1.324(1.047-1.674)$ & $p=0.019$ * \\
\hline & \multicolumn{4}{|c|}{ Lymph node metastasis } \\
\hline rs77996007 & $\begin{array}{l}\text { No } \\
(n=796)(\%)\end{array}$ & $\begin{array}{l}\text { Yes } \\
(n=400)(\%)\end{array}$ & & \\
\hline TT & $313(39.3 \%)$ & $157(39.3 \%)$ & 1.00 & \\
\hline \multirow[t]{2}{*}{$\mathrm{TC}+\mathrm{CC}$} & $483(60.7 \%)$ & $243(60.7 \%)$ & $1.000(0.780-1.282)$ & $p=0.999$ \\
\hline & \multicolumn{4}{|l|}{ Distant metastasis } \\
\hline rs77996007 & $\begin{array}{l}\text { M0 } \\
(n=1034)(\%)\end{array}$ & $\begin{array}{l}\text { M1 } \\
(n=10)(\%)\end{array}$ & & \\
\hline TT & $468(39.5 \%)$ & $2(20.0 \%)$ & 1.00 & \\
\hline \multirow[t]{2}{*}{$\mathrm{TC}+\mathrm{CC}$} & $718(60.5 \%)$ & $8(80.0 \%)$ & $2.645(0.555-12.597)$ & $p=0.222$ \\
\hline & \multicolumn{4}{|c|}{ Cell differentiation grade } \\
\hline rs77996007 & $\begin{array}{l}\leqq \text { Grade I }(n=170) \\
(\%)\end{array}$ & $\begin{array}{l}>\text { Grade I }(n=1026) \\
(\%)\end{array}$ & & \\
\hline TT & $63(37.1 \%)$ & $407(39.7 \%)$ & 1.00 & \\
\hline $\mathrm{TC}+\mathrm{CC}$ & $107(62.9 \%)$ & $619(60.3 \%)$ & $0.889(0.634-1.246)$ & $p=0.494$ \\
\hline
\end{tabular}

Cell differentiate grade: grade I: well differentiated; grade II: moderately differentiated; grade III: poorly differentiated. The adjusted odds ratio (AOR) with their $95 \%$ confidence intervals were estimated by multiple logistic regression models after controlling for age, betel quid chewing, cigarette smoking, and alcohol drinking. ${ }^{*} p$-value $<0.05$ as statistically significant.

2.5. Association between SOX11 mRNA Expression and Clinical Characteristics of HNSCC Tissues from the TCGA Database

Considering the potential effects of SOX11 polymorphic genotypes on SOX11 expression, we further clarified the clinical significance of SOX11 expression in HNSCC tissues from the TCGA database. As shown in Figure 1, the results indicated that SOX11 mRNA levels were upregulated in HNSCC compared with normal tissues (Figure 1A,B). Furthermore, the relative levels of SOX11 mRNA were significantly associated with the tumor status (Figure 1C), clinical T status (Figure 1D), and lymph node metastasis status (Figure 1E) in HNSCC tissues. Moreover, HNSCC samples with copy number loss express significantly higher levels of SOX11 mRNA than tumors diploid $(p=0.0432)$ (Figure 1F). 
(A)

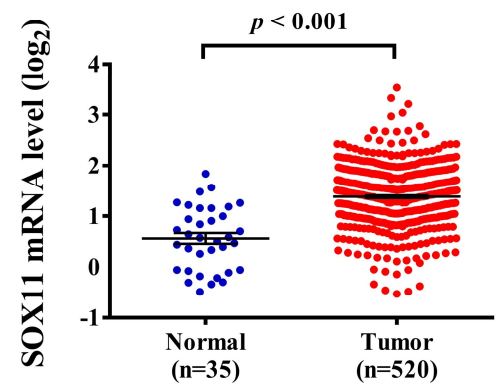

(C)

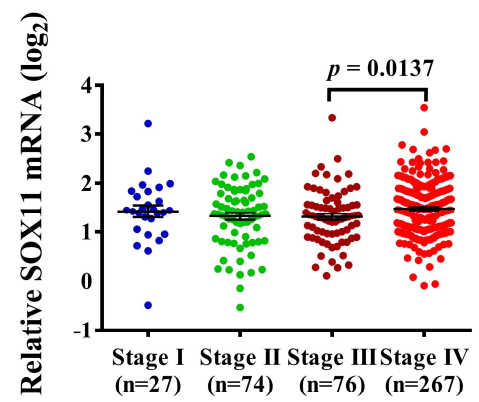

(E)

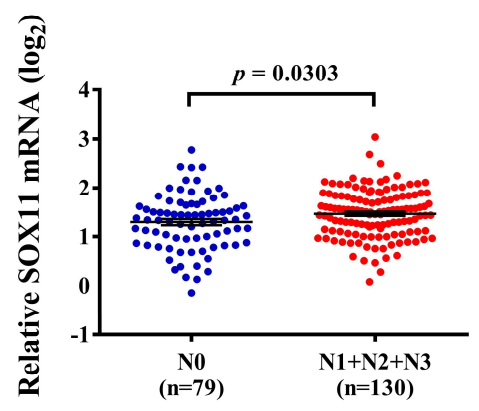

(B)

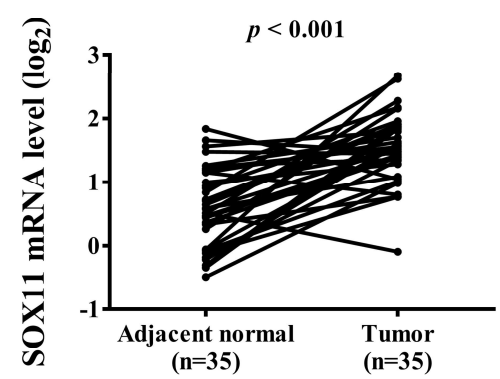

(D)

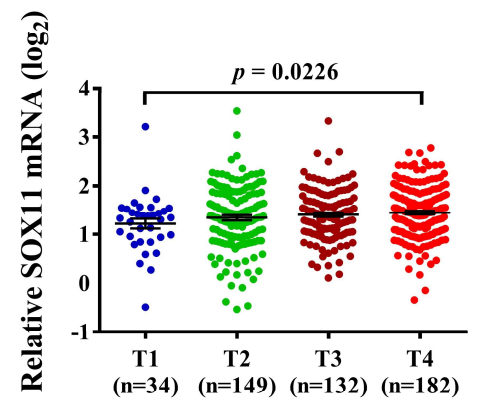

(F)

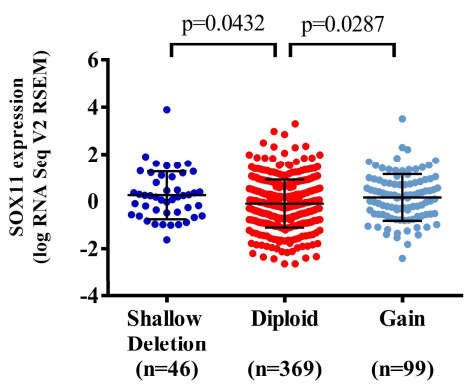

Figure 1. Association of SOX11 mRNA level and clinical status from the TCGA database. (A) The SOX11 mRNA level of HNSCC tissues were compared to normal tissues. (B) The SOX11 mRNA level were compared according to adjacent normal tissues and HNSCC tissues. (C) The SOX11 mRNA levels were compared according to tumor stage. (D) The SOX11 mRNA levels were compared according to tumor clinical T stage. (E) The SOX11 mRNA levels were compared according to clinical $n$ stage. (F) Boxplots of RNA-Seq for SOX11 mRNA demonstrating significantly altered expression in diploid versus deletion and gain cancers.

\section{Discussion}

SOX11 is involved in the processes of several human cancers, including bladder cancer, head and neck cancer and breast cancer. Previous studies have reported a direct association between tumor metastasis and SOX11 expression [18,24-26]. However, the role of SOX11 polymorphisms in oral cancer has rarely been discussed. In the present study, we observed that the combined effect of environmental factors and SOX11 polymorphisms considerably increased the risk of oral cancer. Moreover, patients with SOX11 SNP rs77996007 with a genotype of TC and CC were significantly associated with large tumor size. 
SNPs are among the most common types of genetic variation in the human genome. SNPs widely affect the regulation of genes that are associated with genetic susceptibility to cancer, such as those involved in cell cycle regulation, DNA mismatch repair, metabolism, and immunity [27-29]. Exploring the mechanisms through which SNPs affect cancer susceptibility is conducive to understanding the molecular pathogenesis of various cancers. The mechanism of SNPs can depend on their location within genes, such as promoters, exons, and introns as well as the $5^{\prime}$ - and $3^{\prime}$-untranslated regions (UTRs) [30-32]. Promoter-associated polymorphisms affect the binding of transcription factors to alter promoter activity, further influencing gene transcription, mRNA stability, and translation $[33,34]$.

The three SNPs of SOX11 investigated in this study were localized in the $3^{\prime}$-UTR of the SOX11 gene. The $3^{\prime}$-UTR is a noncoding sequence that closely follows the coding regions of mRNA. The mRNA of nearly all eukaryotes involves $3^{\prime}$-UTR formation [35]; $3^{\prime}$-UTR formation is crucial for maintaining mRNA stability. Additionally, the $3^{\prime}$-UTR plays a major role in several aspects of gene regulation, including translation efficiency, subcellular localization, polyadenylation, and mRNA degradation [36,37]. Previous research revealed that the allelic variants of the SOX11 SNPs in the $3^{\prime}$-UTR may modulate SOX11 expression [38]. These data suggest that SOX11 SNPs in the $3^{\prime}$-UTR have potential transcriptional function. The $3^{\prime}$-UTR can be bound by specific microRNAs (miRNAs), which can inhibit the translation of mRNAs or degrade mRNAs to inhibit their expression [39]. However, the three SOX11 SNPs examined in the present study were determined to be in the $3^{\prime}$-UTR in which miRNAs may interact; therefore, they should be further delineated.

The present study is the first to explore the association between SOX11 SNPs and oral cancer. We revealed the importance of SOX11 variations in the development of oral cancer. However, this study has some limitations. Because the study included only the discovered population and there was no independent study to confirm these findings, our findings regarding the association between the SOX11 variant and oral cancer should be considered preliminary. Moreover, we failed to rule out the possibility of potential selection bias, because the control group was selected from patients without cancer on a hospital basis. In addition, the mechanism through which SOX11 SNPs regulate the development of oral cancer still requires further investigation.

\section{Materials and Methods}

\subsection{Study Population}

Due to the unique epidemiology of oral cancer in Taiwan (with a ratio of almost 10:1 for men and women), this case-control study included 1196 male patients with oral cancer who underwent diagnosis at Changhua Christian Hospital in Changhua and Chung Shan Medical University Hospital in Taichung, Taiwan, between 2007 and 2019. For the control group, we enrolled 1200 healthy male participants aged $>20$ years and without a self-reported history of cancer at any site from Taiwan Biobank. In addition, subjects with oral precancerous disease such as leukoplakia, erythroplakia, etc. were excluded from the control group. Medical information-including primary tumor size, lymph node involvement, histologic grade, and pathologic stage, as determined according to the tumor-node-metastasis (TNM) staging system of the American Joint Committee on Cancer-was obtained from medical records [40]. Participants' personal characteristics and information, including demographic characteristics, betel quid chewing, tobacco smoking, alcohol consumption, and medical histories, were obtained using interviewer-administered questionnaires, and informed written consent was obtained from each individual.

\subsection{Determination of Genotypes}

Genomic DNA from peripheral blood leukocytes was extracted using QIAamp DNA blood mini kits (Qiagen, Valencia, CA, USA) according to the manufacturer's instructions as previously described [41,42]. DNA was quantified by measuring absorbance at $260 \mathrm{~nm}$ and stored at $-20^{\circ} \mathrm{C}$. Allelic discrimination for SOX11 (rs77996007, rs66465560, and rs68114586) was performed using the 
TaqMan SNP genotyping assay (Applied Biosystems, Foster City, CA, USA), and further analysis was performed using SDS 3.0 software (Applied Biosystems).

\subsection{Selection of SOX11 Polymorphisms and Database Analysis}

In the dbSNP database, over 100 SOX11 SNPs have been documented. We investigated SOX11 (rs77996007, rs66465560, and rs68114586), those with minor allele frequencies $\geq 5 \%$ and located at the $3^{\prime}$ UTR regions in the Chinese populations. For the database analysis, the association between SOX11 expression and clinical information of head and neck squamous cell carcinoma (HNSCC) tissues obtained from the Cancer Genome Atlas (TCGA) database was analyzed using GraphPad Prism 6 software (GraphPad Software Inc., La Jolla, San Jose, CA, USA).

\subsection{Statistical Analysis}

Fisher's exact test was used to determine differences in demographic characteristic between healthy controls and oral cancer patients. Adjusted odds ratios (ORs) along with the corresponding 95\% confidence intervals (CIs) for the association between genotype frequencies and the risk of oral cancer plus clinicopathological characteristics were estimated using multiple logistic regression models after other covariates were controlled for. Data were analyzed using SAS 9.1 statistical software (SAS Institute Inc., Cary, NC, USA). A $p$-value of $<0.05$ was considered significant.

\section{Conclusions}

Our results indicate that the allelic effects of SOX11 SNPs increase the risk of oral cancer based on environmental factors, such as tobacco smoking and betel quid chewing. Moreover, in oral cancer patients, SOX11 rs77996007 variants were significantly associated with large tumor size. Our results suggest that SOX11 rs77996007 is involved in the tumor progression of oral cancer.

Author Contributions: Conceptualization, C.-M.Y., C.-W.L., S.-F.Y., and M.-K.C.; methodology, C.-M.Y., and C.-H.C.; formal analysis, C.-M.Y. and C.-H.C.; resources, C.-Y.C., H.-J.L., and M.-K.C.; writing-original draft preparation, C.-M.Y., C.-W.L., S.-F.Y., and M.-K.C.; writing-review and editing, C.-M.Y., C.-W.L., S.-F.Y., and M.-K.C. All authors have read and agreed to the published version of the manuscript.

Funding: This research was funded by the Ministry of Science and Technology, Taiwan (MOST-107-2314-B-371-008-MY3).

Conflicts of Interest: The authors declare no conflict of interest.

\section{Appendix A}

Table A1. The odds ratio (OR) and adjusted odds ratio (AOR) and 95\% confidence interval (CI) of oral cancer associated with SOX11 genotypic frequencies.

\begin{tabular}{|c|c|c|c|c|c|c|}
\hline Variable & $\begin{array}{l}\text { Controls } \\
(n=1200) \\
(\%)\end{array}$ & $\begin{array}{l}\text { Patients } \\
(n=1196) \\
(\%)\end{array}$ & OR $(95 \%$ CI) & $p$ Value & AOR $(95 \% \mathrm{CI})$ & $p$ Value \\
\hline \multicolumn{7}{|l|}{ Age (yrs) } \\
\hline$>55$ & $590(49.2 \%)$ & $587(49.1 \%)$ & $0.997(0.849-1.170)$ & $p=0.966$ & $1.283(1.053-1.564)$ & $p=0.014$ \\
\hline \multicolumn{7}{|c|}{ Betel quid chewing } \\
\hline No & $1001(83.4 \%)$ & $321(26.8 \%)$ & 1.000 (reference) & $p<0.001$ & 1.000 (reference) & $p<0.001$ \\
\hline \multicolumn{7}{|c|}{ Cigarette smoking } \\
\hline No & $564(47.0 \%)$ & $192(16.0 \%)$ & 1.000 (reference) & \multirow[t]{2}{*}{$p<0.001$} & 1.000 (reference) & \multirow[t]{2}{*}{$p=0.006$} \\
\hline Yes & $636(53.0 \%)$ & $1004(84.0 \%)$ & $4.637(3.829-5.616)$ & & $1.398(1.103-1.773)$ & \\
\hline \multicolumn{7}{|c|}{ Alcohol drinking } \\
\hline No & $963(80.2 \%)$ & $648(54.2 \%)$ & 1.000 (reference) & \multirow[t]{2}{*}{$p<0.001$} & 1.000 (reference) & \multirow[t]{2}{*}{$p<0.001$} \\
\hline Yes & $237(19.8 \%)$ & $548(45.8 \%)$ & $3.436(2.864-4.122)$ & & $1.499(1.197-1.877)$ & \\
\hline
\end{tabular}


Table A1. Cont.

\begin{tabular}{|c|c|c|c|c|c|c|}
\hline Variable & $\begin{array}{l}\text { Controls } \\
(n=1200) \\
(\%)\end{array}$ & $\begin{array}{l}\text { Patients } \\
(n=1196) \\
(\%)\end{array}$ & OR $(95 \%$ CI $)$ & $p$ Value & AOR $(95 \%$ CI) & $p$ Value \\
\hline \multicolumn{7}{|l|}{ rs77996007 } \\
\hline $\mathrm{TT}$ & $514(42.8 \%)$ & $470(39.3 \%)$ & 1.000 (reference) & \multirow[t]{2}{*}{$p=0.079$} & 1.000 (reference) & \multirow[t]{2}{*}{$p=0.746$} \\
\hline $\begin{array}{l}\mathrm{TC}+\mathrm{CC} \\
\text { rs66465560 }\end{array}$ & $686(57.2 \%)$ & $726(60.7 \%)$ & $1.157(0.983-1.362)$ & & $1.034(0.844-1.268)$ & \\
\hline TT & $911(75.9 \%)$ & $921(77.0 \%)$ & 1.000 (reference) & \multirow[t]{2}{*}{$p=0.529$} & 1.000 (reference) & \multirow[t]{2}{*}{$p=0.472$} \\
\hline $\begin{array}{l}\mathrm{TC}+\mathrm{CC} \\
\text { rs681145866 }\end{array}$ & $289(24.1 \%)$ & $275(23.0 \%)$ & $0.941(0.779-1.137)$ & & $0.572(0.125-2.619)$ & \\
\hline Ins/Ins & $912(76.0 \%)$ & $921(77.0 \%)$ & 1.000 (reference) & \multirow[t]{2}{*}{$p=0.561$} & 1.000 (reference) & \multirow[t]{2}{*}{$p=0.513$} \\
\hline Ins/Del or Del/Del & $288(24.0 \%)$ & $275(23.0 \%)$ & $0.946(0.783-1.142)$ & & $1.665(0.362-7.650)$ & \\
\hline
\end{tabular}

The adjusted odds ratio (AOR) with their 95\% confidence intervals were estimated by multiple logistic regression models after controlling for age, betel quid chewing, cigarette smoking, and alcohol drinking.

\section{References}

1. Siegel, R.L.; Miller, K.D.; Jemal, A. Cancer statistics, 2019. CA Cancer J. Clin. 2019, 69, 7-34. [CrossRef]

2. Siegel, R.L.; Miller, K.D.; Jemal, A. Cancer statistics, 2018. CA Cancer J. Clin. 2018, 68, 7-30. [CrossRef]

3. van der Waal, I. Are we able to reduce the mortality and morbidity of oral cancer; some considerations. Med. Oral Patol. Oral. Cir. Bucal 2013, 18, e33-e37. [CrossRef] [PubMed]

4. Su, S.C.; Chang, L.C.; Lin, C.W.; Chen, M.K.; Yu, C.P.; Chung, W.H.; Yang, S.F. Mutational signatures and mutagenic impacts associated with betel quid chewing in oral squamous cell carcinoma. Hum. Genet. 2019, 138, 1379-1389. [CrossRef]

5. Su, S.C.; Lin, C.W.; Liu, Y.F.; Fan, W.L.; Chen, M.K.; Yu, C.P.; Yang, W.E.; Su, C.W.; Chuang, C.Y.; Li, W.H.; et al. Exome sequencing of oral squamous cell carcinoma reveals molecular subgroups and novel therapeutic opportunities. Theranostics 2017, 7, 1088-1099. [CrossRef]

6. Schepers, G.E.; Teasdale, R.D.; Koopman, P. Twenty pairs of sox: Extent, homology, and nomenclature of the mouse and human sox transcription factor gene families. Dev. Cell 2002, 3, 167-170. [CrossRef]

7. She, Z.Y.; Yang, W.X. Sox family transcription factors involved in diverse cellular events during development. Eur. J. Cell Biol. 2015, 94, 547-563. [CrossRef]

8. Bowles, J.; Schepers, G.; Koopman, P. Phylogeny of the sox family of developmental transcription factors based on sequence and structural indicators. Dev. Biol. 2000, 227, 239-255. [CrossRef]

9. Koopman, P.; Gubbay, J.; Vivian, N.; Goodfellow, P.; Lovell-Badge, R. Male development of chromosomally female mice transgenic for sry. Nature 1991, 351, 117-121. [CrossRef]

10. Hou, L.; Srivastava, Y.; Jauch, R. Molecular basis for the genome engagement by sox proteins. Semin. Cell Dev. Biol. 2017, 63, 2-12. [CrossRef]

11. Sarkar, A.; Hochedlinger, K. The sox family of transcription factors: Versatile regulators of stem and progenitor cell fate. Cell Stem Cell 2013, 12, 15-30. [CrossRef] [PubMed]

12. Jay, P.; Goze, C.; Marsollier, C.; Taviaux, S.; Hardelin, J.P.; Koopman, P.; Berta, P. The human sox11 gene: Cloning, chromosomal assignment and tissue expression. Genomics 1995, 29, 541-545. [CrossRef] [PubMed]

13. Sock, E.; Rettig, S.D.; Enderich, J.; Bosl, M.R.; Tamm, E.R.; Wegner, M. Gene targeting reveals a widespread role for the high-mobility-group transcription factor sox11 in tissue remodeling. Mol. Cell. Biol. 2004, 24, 6635-6644. [CrossRef] [PubMed]

14. Shepherd, J.H.; Uray, I.P.; Mazumdar, A.; Tsimelzon, A.; Savage, M.; Hilsenbeck, S.G.; Brown, P.H. The sox11 transcription factor is a critical regulator of basal-like breast cancer growth, invasion, and basal-like gene expression. Oncotarget 2016, 7, 13106-13121. [CrossRef] [PubMed]

15. Wasik, A.M.; Lord, M.; Wang, X.; Zong, F.; Andersson, P.; Kimby, E.; Christensson, B.; Karimi, M.; Sander, B. Soxc transcription factors in mantle cell lymphoma: The role of promoter methylation in sox11 expression. Sci. Rep. 2013, 3, 1400. [CrossRef] 
16. Xu, X.; Chang, X.; Li, Z.; Wang, J.; Deng, P.; Zhu, X.; Liu, J.; Zhang, C.; Chen, S.; Dai, D. Aberrant sox11 promoter methylation is associated with poor prognosis in gastric cancer. Cell. Oncol. (Dordr) 2015, 38, 183-194. [CrossRef]

17. Sernbo, S.; Gustavsson, E.; Brennan, D.J.; Gallagher, W.M.; Rexhepaj, E.; Rydnert, F.; Jirstrom, K.; Borrebaeck, C.A.; Ek, S. The tumour suppressor sox11 is associated with improved survival among high grade epithelial ovarian cancers and is regulated by reversible promoter methylation. BMC Cancer 2011, 11, 405. [CrossRef] [PubMed]

18. Xiao, Y.; Xie, Q.; Qin, Q.; Liang, Y.; Lin, H.; Zeng, D. Upregulation of sox11 enhances tamoxifen resistance and promotes epithelial-to-mesenchymal transition via slug in mcf-7 breast cancer cells. J. Cell. Physiol. 2020, in press. [CrossRef]

19. Sunyaev, S.; Ramensky, V.; Koch, I.; Lathe, W., 3rd; Kondrashov, A.S.; Bork, P. Prediction of deleterious human alleles. Hum. Mol. Genet. 2001, 10, 591-597. [CrossRef]

20. Yadav, A.; Gupta, A.; Rastogi, N.; Agrawal, S.; Kumar, A.; Kumar, V.; Mittal, B. Association of cancer stem cell markers genetic variants with gallbladder cancer susceptibility, prognosis, and survival. Tumour Biol. 2016, 37, 1835-1844. [CrossRef]

21. Tulsyan, S.; Agarwal, G.; Lal, P.; Mittal, B. Significant association of combination of oct4, nanog, and sox2 gene polymorphisms in susceptibility and response to treatment in north indian breast cancer patients. Cancer Chemother. Pharm. 2014, 74, 1065-1078. [CrossRef] [PubMed]

22. Bafligil, C.; Thompson, D.J.; Lophatananon, A.; Smith, M.J.; Ryan, N.A.; Naqvi, A.; Evans, D.G.; Crosbie, E.J. Association between genetic polymorphisms and endometrial cancer risk: A systematic review. J. Med. Genet. 2020, in press. [CrossRef]

23. Elzakra, N.; Cui, L.; Liu, T.; Li, H.; Huang, J.; Hu, S. Mass spectrometric analysis of sox11-binding proteins in head and neck cancer cells demonstrates the interaction of sox11 and hsp90 $\alpha$. J. Proteome Res. 2017, 16, 3961-3968. [CrossRef] [PubMed]

24. Huang, J.; Ji, E.H.; Zhao, X.; Cui, L.; Misuno, K.; Guo, M.; Huang, Z.; Chen, X.; Hu, S. Sox11 promotes head and neck cancer progression via the regulation of sdccag8. J. Exp. Clin. Cancer Res. 2019, 38, 138. [CrossRef] [PubMed]

25. Wu, Z.; Huang, W.; Wang, X.; Wang, T.; Chen, Y.; Chen, B.; Liu, R.; Bai, P.; Xing, J. Circular rna cep128 acts as a sponge of mir-145-5p in promoting the bladder cancer progression via regulating sox11. Mol. Med. 2018, 24, 40. [CrossRef] [PubMed]

26. Petrakis, G.; Veloza, L.; Clot, G.; Gine, E.; Gonzalez-Farre, B.; Navarro, A.; Bea, S.; Martinez, A.; Lopez-Guillermo, A.; Amador, V.; et al. Increased tumour angiogenesis in sox11-positive mantle cell lymphoma. Histopathology 2019, 75, 704-714. [CrossRef]

27. Devilee, P.; Rookus, M.A. A tiny step closer to personalized risk prediction for breast cancer. N. Engl. J. Med. 2010, 362, 1043-1045. [CrossRef]

28. Hung, S.C.; Chou, Y.E.; Li, J.R.; Chen, C.S.; Lin, C.Y.; Chang, L.W.; Chiu, K.Y.; Cheng, C.L.; Ou, Y.C.; Wang, S.S.; et al. Functional genetic variant of $\mathrm{ww}$ domain containing oxidoreductase gene associated with urothelial cell carcinoma clinicopathologic characteristics and long-term survival. Urol. Oncol. 2020, 38, e41-e49. [CrossRef]

29. Su, C.W.; Chien, M.H.; Lin, C.W.; Chen, M.K.; Chow, J.M.; Chuang, C.Y.; Chou, C.H.; Liu, Y.C.; Yang, S.F. Associations of genetic variations of the endothelial nitric oxide synthase gene and environmental carcinogens with oral cancer susceptibility and development. Nitric Oxide 2018, 79, 1-7. [CrossRef]

30. Steri, M.; Idda, M.L.; Whalen, M.B.; Orrù, V. Genetic variants in mrna untranslated regions. Wiley Interdiscip. Rev. RNA 2018, 9, e1474. [CrossRef]

31. Hua, K.T.; Liu, Y.F.; Hsu, C.L.; Cheng, T.Y.; Yang, C.Y.; Chang, J.S.; Lee, W.J.; Hsiao, M.; Juan, H.F.; Chien, M.H.; et al. $3^{\prime}$ utr polymorphisms of carbonic anhydrase ix determine the mir-34a targeting efficiency and prognosis of hepatocellular carcinoma. Sci. Rep. 2017, 7, 4466. [CrossRef] [PubMed]

32. Tung, M.C.; Wen, Y.C.; Wang, S.S.; Lin, Y.W.; Chow, J.M.; Yang, S.F.; Chien, M.H. Impact of long non-coding rna hotair genetic variants on the susceptibility and clinicopathologic characteristics of patients with urothelial cell carcinoma. J. Clin. Med. 2019, 8, 282. [CrossRef] [PubMed]

33. Park, W.S.; Cho, Y.G.; Park, J.Y.; Kim, C.J.; Lee, J.H.; Kim, H.S.; Lee, J.W.; Song, Y.H.; Park, C.H.; Park, Y.K.; et al. A single nucleotide polymorphism in the e-cadherin gene promoter-160 is not associated with risk of korean gastric cancer. J. Korean Med. Sci. 2003, 18, 501-504. [CrossRef] [PubMed] 
34. Shin, Y.; Kim, I.J.; Kang, H.C.; Park, J.H.; Park, H.R.; Park, H.W.; Park, M.A.; Lee, J.S.; Yoon, K.A.; Ku, J.L.; et al. The e-cadherin -347g->ga promoter polymorphism and its effect on transcriptional regulation. Carcinogenesis 2004, 25, 895-899. [CrossRef]

35. Barrett, L.W.; Fletcher, S.; Wilton, S.D. Regulation of eukaryotic gene expression by the untranslated gene regions and other non-coding elements. Cell. Mol. Life Sci. 2012, 69, 3613-3634. [CrossRef]

36. Zhao, W.; Blagev, D.; Pollack, J.L.; Erle, D.J. Toward a systematic understanding of mrna $3^{\prime}$ untranslated regions. Proc. Am. Thorac. Soc. 2011, 8, 163-166. [CrossRef]

37. Mayr, C. Regulation by 3'-untranslated regions. Annu. Rev. Genet. 2017, 51, 171-194. [CrossRef]

38. Sun, C.P.; Sun, D.; Luan, Z.L.; Dai, X.; Bie, X.; Ming, W.H.; Sun, X.W.; Huo, X.X.; Lu, T.L.; Zhang, D. Association of sox11 polymorphisms in distal 3'utr with susceptibility for schizophrenia. J. Clin. Lab. Anal. 2020, e23306. [CrossRef]

39. Didiano, D.; Hobert, O. Molecular architecture of a mirna-regulated 3' utr. RNA 2008, 14, 1297-1317. [CrossRef]

40. Edge, S.B.; Compton, C.C. The american joint committee on cancer: The 7 th edition of the ajcc cancer staging manual and the future of tnm. Ann. Surg. Oncol. 2010, 17, 1471-1474. [CrossRef]

41. Su, S.C.; Hsieh, M.J.; Lin, C.W.; Chuang, C.Y.; Liu, Y.F.; Yeh, C.M.; Yang, S.F. Impact of hotair gene polymorphism and environmental risk on oral cancer. J. Dent. Res. 2018, 97, 717-724. [CrossRef] [PubMed]

42. Su, S.C.; Hsieh, M.J.; Liu, Y.F.; Chou, Y.E.; Lin, C.W.; Yang, S.F. Adamts14 gene polymorphism and environmental risk in the development of oral cancer. PLOS ONE 2016, 11, e0159585. [CrossRef] [PubMed]

(C) 2020 by the authors. Licensee MDPI, Basel, Switzerland. This article is an open access article distributed under the terms and conditions of the Creative Commons Attribution (CC BY) license (http://creativecommons.org/licenses/by/4.0/). 